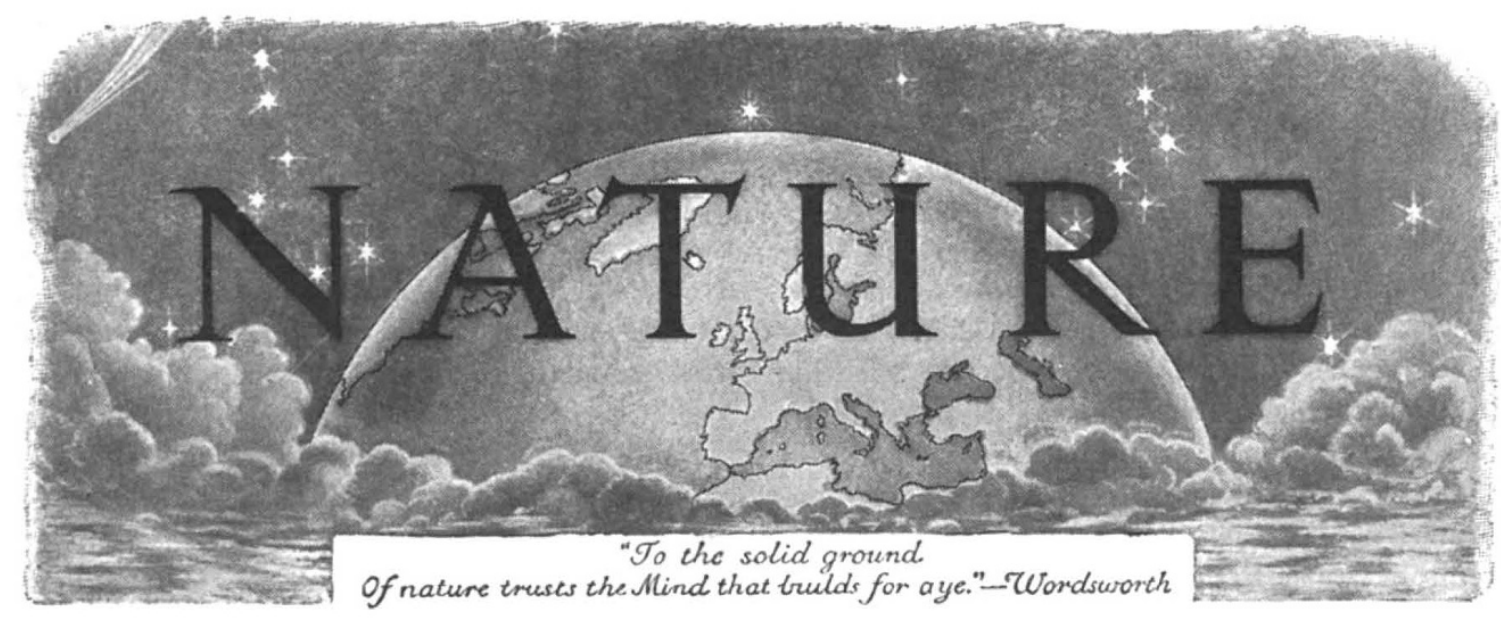

Vol. 143

SATURDAY, JANUARY 7, 1939

No. 3610

\title{
Retrospect and Prospect
}

$\mathrm{T}$ HE public announcement of my retirement from the editorship of NaTuRE was made only a few days before my departure for the United States to deliver the Elihu Root Lecture at the Carnegie Institution of Washington on December 8 , and to give a few other addresses at universities, as well as at the Richmond meeting of the American Association, on social and international aspects of science. Before leaving England, it was not possible for me to thank more than a few of my personal and other friends for their kind messages, but to them, and to all who have helped me with contributions and advice during the forty-five years of my association with Nature, first as assistant editor to Sir Norman Lockyer, and later as editor, I welcome the opportunity now given me of expressing my very grateful appreciation of their interest and aid.

Throughout its existence, NATURE has had the active support of leading workers in scientific fields in many parts of the world. The aim has always been to record results of research of wide interest or particular importance wherever it has been carried out, and to present authoritative thought and opinion upon progressive scientific developments and their influence. In the early years of the journal, there was little recognition of the practical services which science can render to industry, or of the place which it should occupy in a modern State. Appeals for endowment of scientific research were perversely described as implying the search of scientific workers themselves for endowment in privileged positions rather than as a means of promoting intellectual and industrial progress. Much still remains to be done before our statesmen and industrial leaders are fully aware of the power which science can give to the community, both socially and materially, yet the general principle that expenditure on research is a profitable investment may be said to have been conceded.

Forty-five years ago, the annual grants of the British Government for scientific investigation and related subjects, as shown in the Civil Estimates, were about $£ 45,000$. At the present time, they amount to nearly $£ 2,000,000$, of which the Department of Scientific and Industrial Research administers about $£ 700,000$. Less than one quarter of the net expenditure of the Department represents, however, grants for purposes directly or indirectly connected with industry; and the actual annual economies introduced into industries as the result of research have a financial value many times greater than the amounts expended upon them. On the most generous estimate, the grants for direct and indirect support of scientific research in Great Britain, including those expended in departments of armed forces, represent only one tenth of one per cent of the national income. While, therefore, it is gratifying to be able to record that the policy of State endowment of scientific research consistently advocated in Nature has been accepted, industrial and social conditions are now changing so rapidly that a much bolder and broader financial scheme will have to be undertaken if the advancing front of 
knowledge is to be made available for wise planning and efficient action in times of peace or of war.

Even, however, when adequate provision has been made for scientific research in biological as well as physical fields, whether purely with the object of increasing natural knowledge or for the purpose of industrial development, scientific workers will neglect their special responsibilities as citizens if they are indifferent to the social consequences of their discoveries. To the enlightened public, science signifies the disinterested pursuit of truth by patient observation, critical inquiry, unprejudiced examination of evidence and convincing judgment; but there are still many people who associate it with the conversion of pleasant natural scenes into industrial slums and with clouds of poison gas and other barbarous means of destroying man and his noblest works. It is the duty of scientific workers on one hand to do nothing which would shake the confidence of the community in the principles for which they stand, and on the other to take every opportunity to absolve themselves of responsibility for the prostitution of the gifts with which they endow the human race. It would be a betrayal of the scientific movement if those who represent it failed to play an active part in solving the social problems which their contributions to natural knowledge have created.

It is with such social and international relationships of science that Nature has been largely concerned during the past twenty years or so ; and the recent formation of the new Iivision of the British Association, as well as the steps taken by the American Association and similar organizations of scientific workers to make their promotion a common cause, represent the beginning of an international movement which may save the world from the disasters now threatening it.

The correspondence columns of NATURE have become an international clearing-house of contributions to natural knowledge ; and in this field the standard of value is independent of race or nationality or any other measure than originality and scientific worth. Liberty of thought and action are essential for creative scientific work; and progress is impossible when restrictions are placed upon them.

These principles of scientific freedom have been won through generations of struggle with Church and State, and when science neglects to assert them as fundamental conditions of creative work it will commit suicide. The policy of Nature is to establish these rights not only in the interests of scientific workers themselves but also in those of the whole community. My particular mission has been to make men of science conscious of their power and influence in shaping civilized life, and I am happy to know that my successors will continue to proclaim this message as an inspiring intellectual stimulus and a means of promoting the welfare and the brotherhood of the human race.

R. A. Gregory.

\section{Science for Africa}

\section{An African Survey:}

a Study of Problems arising in Africa south of the Sahara. By Lord Hailey. (Issued by the Committee of the African Research Survey under the auspices of the Royal Institute of International Affairs.) Pp. xxviii+1838. (London, New York and Toronto: Oxford University Press, 1938.) 21s. net.

F OLLOWING an appeal for a comprehensive survey of Africa and its problems made by General Smuts in his Rhodes Memorial Lecture in 1929, an authoritative committee was formed to give effect to his proposal. Thanks to the generosity and vision of the Carnegie Corporation of New York, funds were made available, and Lord Hailey agreed to undertake the task on his retirement from the governorship of the United Provinces in India. Five years intensive work has produced a comparative study of the countries, peoples and their indigenous institutions and the influence of the different European Colonial Powers on the development of both in connexion with the exploitation of the natural resources of the whole of the mainland of Africa lying south of the Sahara, with the exception of the Anglo-Egyptian Sudan, the Italian possessions and Liberia. The survey therefore covers an area in which a Dominion of the British Commonwealth, Great Britain, France, Belgium and Portugal "are engaged in a common task, though in some respects with widely different methods of approach".

"The sole object for undertaking the Survey", says Lord Hailey, "was the hope that it might prove of some service to the Powers which have possession of territories in Africa, and of some 